\title{
SCIENTIFIC JOURNAL “PHYSICAL CULTURE” ON THE MISSION TO DEVELOP SCIENTIFIC AND SOCIAL COMMUNITY
}

\author{
Branislav Jevtić \\ University of Belgrade, Faculty of Sport and Physical Education, Serbia
}

\begin{abstract}
Modern universities have become the backbone of an economy based on knowledge and innovative policy. They deal with problems of society, primarily the needs for general development, as well as with the problems neglected or "unfulfilled" by public authorities. In Serbia, a project is being realized, which, in addition to the existing two missions (teaching and research), should also develop and implement the universities' third mission which consists of the following three pillars of development: knowledge transfer - technology and innovations, continuous learning, and the acquisition and application of socially responsible behaviour by the universities in Serbia. The changes leading to a modern entrepreneurial university should be followed and accompanied by the changes in scientific journals' missions, since the common denominator of knowledge creators and disseminators is the prosperity of science and society based on innovations. Accordingly, the subject matter of this paper refers to the university's assumed role in the community development or to the capacity of the "Physical Culture" scientific journal to become an intermediary between the teaching, scientific and social mission of the „Physical Education and Sport” science.
\end{abstract}

Key words: UNIVERSITIES’ THIRD MISSION / ENTREPRENEURSHIP / PHYSICAL ACTIVITY / SCIENTIFIC JOURNAL / SERBIA

\section{INTRODUCTION}

Higher education has been depicted and determined by teaching and research activities, which, depending on the period of the universities' development, were in favour of the founders (church, rulers, governments ...) and the owners. History teaches us that the university's mission is dynamic and variable, that it is the result of philosophical ideas, educational policies, culture of the society, and the development of the university itself as an institution (Sccot, 2009). The university's mission is also established in relation to goals, such as the development of democracy, progress, war and peace, humanity.... However, it is always in the function of social welfare (Figure 1).

Observing the development of higher education through the dimension of time, we may notice a "competition" over dominance between teaching and scientific activity. In the past ninety years there has been a tendency towards the affirmation of its "third mission", which is aimed at the community and society development. At the beginning of the 1930s, the universities in the United States expressed their aspiration towards a "university triad”, i.e. the need to become the institutions which include the unity of teaching, research as well as public influence and social significance (Clancy and Dill, 2009). Thus, in regard to 930 years of university education, two interdependent processes can be observed, out of which the first one is associated with national aspiration (a mission to protect national culture and social well-being), while the second one relates to international aspiration (global influence and international ranking) (Kurbatov , 2015). Accordingly, the subject matter of this paper relates to the university's assumed role in the community development, i.e. to the capacity of the "Physical Culture" scientific journal to become an intermediary between the teaching, scientific and social mission of the science of "Physical Education and Sport". 


\section{$3^{\text {th }}$ PERIOD: Autonomy of teaching and research -} public function of the university

\begin{tabular}{|c|c|}
\hline $\begin{array}{c}\text { International mission of } \\
\text { University - Globalization } \\
\text { Educated and informational societies } \\
\text { Socio-political and corporate mission } \\
\text { Journals, books, databases } \\
=\text { Communication of the world }\end{array}$ & $\begin{array}{l}\text { Education and Research - University of the } \\
\text { 19th Century (Humbold) - } \\
\text { Democratization and public function } \\
\text { In the United States (1800) - freedom and self- } \\
\text { guidance } \\
\text { Humanistic ontology } \\
\text { Ethical principles for professors and } \\
\text { students }\end{array}$ \\
\hline $\begin{array}{c}\mathbf{4}^{\text {th }} \text { PERIOD: University of } \\
\text { the Era of Globalization }\end{array}$ & $\begin{array}{c}\mathbf{1}^{\text {st }} \text { PERIOD: } \\
\text { Sholastic University }\end{array}$ \\
\hline $\begin{array}{l}\text { University of limited autonomy } \\
\text { and with the mission of the founder (government } \\
\text { religious dignitaries } \\
\text { national states ....) }\end{array}$ & $\begin{array}{c}\text { Mission of the University: } \\
\text { Education }=\text { Trivium }+ \text { Kvadrivium }= \\
\text { Seven free sciences } \\
\text { (grammar, rhetoric, dialectics } \\
+ \text { arithmetic, geometry, astronomy, music) } \\
\text { Education in the function of church and secular } \\
\text { professions }\end{array}$ \\
\hline
\end{tabular}

\section{$2^{\text {nd }}$ PERIOD: University of limited autonomy}

Figure 1. Periods of development and dynamics of the university's mission (presentation based on Clancy and Dill 2009)

\section{INNOVATION AND UNIVERSITIES' THIRD MISSION}

A characteristic of modern society is general development based on initiatives, creativity and innovations. Thus, the capacity of a society is measured by its economic development, within which a level of innovation is dominant. According to the European Innovation Scoreboard 2017 Serbia belongs to the "Moderate Innovators” group of countries. This group is preceded by the groups „Innovation Leaders" (Switzerland ...) and „Strong Innovators” (Slovenia ...). With an innovation index of 64.2, Serbia is ranked $28^{\text {th }}$, followed by eight countries, six of which are the EU members (EU index 2017).

Pursuant to the Law on Higher Education of Serbia from 2017, the Article 59, paragraph 3, taken from the 2005 Law, it is defined that in order to commercialize the results of scientific research or artistic work, the university-faculties can establish scientific institutes, innovation centres, centres of excellence, technology transfer centres, business technology incubator, science and technology incubator, science and technology park and other organizations for performing innovation activities and providing infrastructural support for the innovation development and the commercialization of research results. Social justification and the utilization of scientific research results has not been recognized thereby, and the specification of the purpose and meaning of the term innovation has not been performed either. Nevertheless, we should believe and hope that the legislator implied not only the innovations that will stimulate the commercialization of results, economic development and enhanced financial independence of the faculties themselves, but that he primarily assumed that innovations also apply to social development as well as to the development of entrepreneurial capacity and students' competences. The Figure 2 shows the "Mission of Modern Innovation University", which was modified by the author bearing in mind the "third mission” of the universities. 


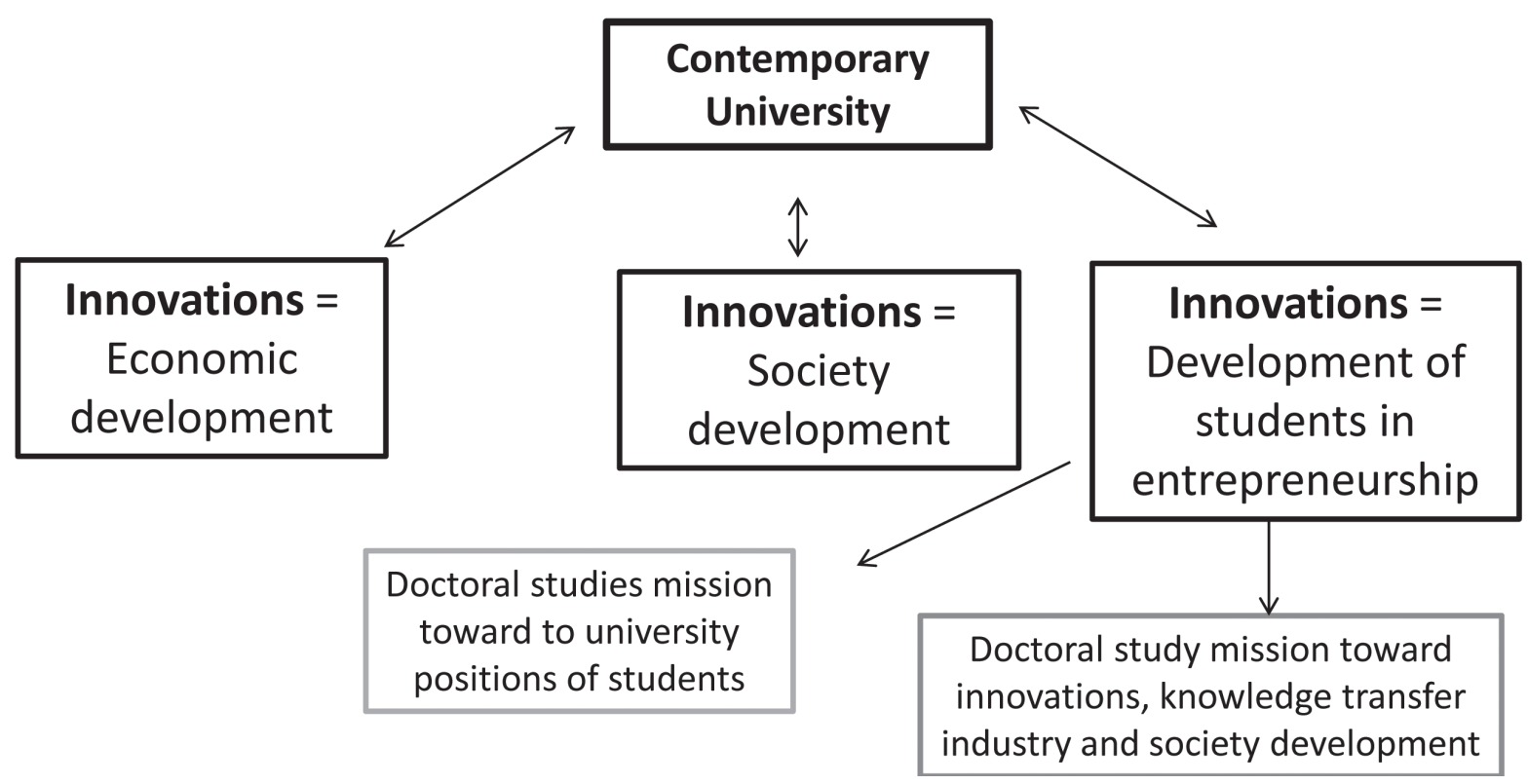

Figure 2. Mission of modern innovation university (Clancy and Dill, 2009)

Even by a cursory glance at the laws that determined higher education in Serbia until 2005, the presence of a great number of the articles which regulated the teaching activity and the core affiliation of faculties regarding certain scientific fields may be noticed. The Laws adopted after 2005 have terminated the regulation of the organization of teaching activity of universities and faculties (the universities' first mission). Instead of developing the universities” „first mission", the legislator introduced the articles which define and describe the functioning of bodies responsible for quality assurance, accreditation, management of higher education courses ... Today, after the adoption of the Law on Higher Education (2017), all of these bodies have been made "state-ruled", which has directly jeopardized the autonomous development of higher education. A new dispute between the state and the academic community has been entered into, the Law has been challenged by universities, National Council of Higher Education, Commission for Accreditation and Quality Assurance, Serbian Academy of Sciences and numerous professors and researchers. „The Law decreases the level of the autonomy of educational institutions, which is why the Serbian Academy of Sciences and Arts especially demands the amendments to the newly adopted law or the adoption of a new one." There is no reply by the other party - the state, it is expected to act according to the adopted law. In the following six months, in si- lence, and in agreement to abandon the emancipation of all three missions, the adoption of special documents (statutes) will take place, both at universities, faculties and scientific institutes. Thus, at the end of the second decade of the $21^{\text {st }}$ century, the Serbian academic community will voluntarily vote for the statutes by which it will renounce not only its autonomy, but also the integration and decentralization of higher education. The state, as the university owner, has once again become the holder of higher education, just like the rulers used to be in the past. It has been given a key role, not only in the area of establishment, organization and funding, but primarily in a part of the process of accreditation and issuing working licenses of each individual higher education institution. This circulus vitiosus between the lawmakers and the beneficiaries of the law reflects the reality in Serbia of the $21^{\text {st }}$ century whereby the entity of its higher education has been returned to the second stage of university development (Figure1)! How to establish a free and autonomous university, how to reach the next developmental stages dominated by the university that ensures progress to the community- society by which it is funded and when, all of this will remain unknown to the author as well as to the generations of teachers, associates and researchers at the universities in Serbia. 


\section{Entrepreneurial intentions and universities' "third mission"}

"The analysis of the curriculums taught at the universities in Serbia has indicated that they are outdated, lagging behind the modern needs and challenges of society, that the profiles that are being educated are greatly inconsistent with the needs of society. Studies are managed by the curiosity and interests of researchers and professors, and, to a lesser extent, by the needs of society. Scientific publication is the basic criterion for selecting teachers, which is the main incentive factor for the research for libraries and career development instead of the research to address the needs of society" (Domazet, 2014). On the other hand, Pupavac (2014), who considers higher education the greatest success of a social state, has stated that in Croatia 36,000 students graduate annually, in Serbia 45,000 students, and in Bosnia and Herzegovina there are 18,000 students who graduate on annual basis. He has also added that the teaching and scientific industry of this region has changed a little in relation to the time when Aristotle was teaching at the Lyceum in Athens, and that these systems have been educating students preparing them for traditional and non-innovative careers, but not for the economics and social progress based on innovations and knowledge (Bubble Education).

While the time in the geographical areas included in the analyses of Domazet (2014) and Pupovac (2014) seems to be standing or going back, the contemporary universities have been adapting to their corporate mission and are increasingly recognized as entrepreneurial institutions within which the research results significant for progress - a new economic theory and practice (through economic entrepreneurship) and social reality (through social entrepreneurship) have been intentionally publicated and published (Brooks, 2007). The innovative and entrepreneurial mission, both in economic as well as in social entrepreneurship, has been accompanied by a change in research funding from the traditional - linear model to the national - innovative model that was first developed in Scandinavian countries, and which includes the concept of applying science in the function of the sustainable social development (Clancy and Dill, 2009).

Modern universities are becoming a backbone of the economy based on knowledge and innovation policy (Hagen, 2008). They deal with the problems of society, primarily the needs of its general development, as well as with the problems that are "neglected or unfulfilled" by public authorities and private sector (Rat- ten, 2011a). The path to reaching these goals of the national and supranational university education implies (Clancy and Dill, 2009): (i) progress in teaching and its organization, (i) increasing the quality of research and its relationship with teaching, industry and society (business aspect), (i) emphasis on quality evaluation (normative and objective aspect of teaching outcomes and research results), (i) knowledge transfer organization, (i) knowledge application and social activity plan (sociological and applicable aspect of knowledge) ...

The strategy of the „entrepreneurial university” approach evaluates the output criteria, unlike the input ones which are assessed in Serbia (budget, number of students, number of teachers, size of buildings, library fund, etc.). The output criteria, such as number of innovations, number of employed graduates, social justification of curriculum, teaching and research, economic justification and benefits, transfer of knowledge into the business environment, patents, graduates' awards, organizational effectiveness, number of newly established business units, etc. are only some of the criteria of successful universities and the basis for their ranking. Today, it is hard to imagine a university that manages to survive by the transfer of tacit (unstructured) knowledge. In this regard, especially in developing a strategy for a new research and social paradigm of the faculties in the field of sports and physical education, a search for the meaning of social progress and the methodology of the "community engaged research", which has been pursued, should be added to the continuum of scientific research, which extends from basic to applied research; non-experts should be involved as partners in the implementation of innovations and research findings. This is a type of research and a way in which science communicates with the community (McDonald, 2011).

The changes from the traditional Hubolt's approach to the modern - entrepreneurial university must also be followed and accompanied by a change in the mission of scientific journals, since the common denominator of knowledge creators and disseminators must be a duality, which is the prosperity of science and society based on innovations. In this direction and for this purpose, the changes in the outcomes of doctoral studies have been taking place, which, in addition to qualifying scientific youth for carrying out university tasks (teaching and science), are also aimed at providing doctoral candidates as research leaders for the development programs regarding industry as well as society itself (Figure 2) (Sccot, 2009). The universities 
and faculties that comprehensively perceive their social mission as the first step in the realization of their third mission, as its most critical part, have been establishing offices for knowledge transfer, with the aim of linking creators and users of knowledge. On this path, the capacity of scientific journals should be recognized as one of the means of innovation transfer. In Serbia, in the field of sports and physical education, there is the leading national scientific journal titled „Physical Culture".

At this point and in support of the discussion on the university's third mission, Serbian participation in the international consortium in the implementation of the project „Institutional framework for the development of the third mission of the universities in Serbia" should also be mentioned. The implementation of this project started on October $15^{\text {th }} 2015$ and should be completed in October 2018. The project is co-financed under the ERASMUS PLUS program of the European Union, and it is realized by a consortium of 18 partners including five European universities and six Serbian universities. The main aim of the project is to develop and implement the third mission (Development of society and community) which consists of three pillars of development, namely: knowledge transfer - technology and innovation, continuous learning as well as the acquisition and application of socially responsible behaviour by the Serbian universities, in addition to the existing two missions related to education and research at the universities in Serbia.

\section{THE SCIENCE OF “PHYSICAL EDUCATION AND SPORT” AND UNIVERSITIES' THIRD MISSION}

Physical education, sports and physical recreation have a significant social role and great responsibility. The analysis conducted in Australia has shown the great capacity of sports and physical education in the area of socially responsible behaviour, but it has also determined the factors that could affect the area of community prosperity. Smith and Westerbeck (2007) have determined "strong communication power" of physical activity through which it is possible to reach each member of the community. As a consequence, physical activity is the first tool in the "Appeal to the Young" regarding their growing up in the family, sports, education, culture, community (participants, fans). „Positive health impact” is an ideal platform for the activity and awareness in regard to the health issues of each community member. The following are the factors of physical activity which stimulate: (i) the „community interaction , both in functional sense and in its democratization, a tendency towards peace, social cohesion, joy ..., (i) „awareness of sustainability” and zero tolerance for environmental degradation; (i) ,cultural identification and integration”; (i) „immediate well-being resulting from satisfaction", which, as such, inspires the community members to practice, support and highly appreciate physical activity. Similar conclusions have been drawn by the authors in the case of responsible behaviour of professional sports clubs in the United States (Bieganek, Huber, 2015). Regarding the relationship between physical education, sports and physical recreation in relation to the benefits of the British society, a unique practice, it may be said, has been developed by Margaret Talbot (2002) through her scientific arguments and examples of good practice. An extensive study on the benefits of physical activity on the children's proper growth and integral development has been developed in the scientific monograph „Children's Sports from Practice to the Academic Field", by a group of authors from the Faculty of Sport and Physical Education in Belgrade (Jevtic et al, 2011).

The current understanding of higher education in Serbia, and therefore of the academic activities of university units (faculties) in the field of the science of Sport and Physical Education (SSPE), is mainly related to teaching and science. The analysis of the missions of some faculties in the field of SSPE has indicated a lack of orientation towards the realization of the third mission of the university, which has made the universities across the world successful and which is responsible for the social, economic and cultural development of the community to which the university belongs (Vorley, Nellies, 2009). Thus, the Faculty of Sport and Physical Education takes over its mission from the mission of the University of Belgrade, whereby, intentionally or not, it has been giving up its identity and specificity, which has been built for eighty years, during which the "achieved values" and the accomplished results have been bringing honour to higher education, Serbian society and even to the University of Belgrade itself. On the official web site it has been stated that the mission of this faculty is ,ensuring the highest academic standards and acquiring knowledge and skills in accordance with the needs of society and envisaged national development, as well as a permanent commitment to improving the quality of higher education and 
its inclusion in a single European framework of Higher Education". Obviously, this statement lacks the internal perception of the profession to which it belongs, the purpose of existence, i.e., the contribution to students, profession, the community, the next generations ... (its external mission) cannot be observed. The faculties in Niš and Priština (relocated in Leposavić) perceive their missions identically, i.e. as "Securing one of the leading positions in education of the staff involved in sports, physical education and recreation .... It is difficult to determine a position and a role of the faculties in a society when their mission has been set up as a national competition regarding who will be better in qualifying the staff. It is hard to (determine) claim that the mentioned faculties are aware of their „multi-dimensional functions" in the area of culture, art, science and economy of the society to which they belong, and which pays for their operations. The specified mission statements raise the question of whether these faculty units are obsolete or contemporary in regard to the outcomes and purpose of their existence, or whether they envisage their development through the creation of a new product (for which there is a significant and growing attention), or through maintaining the existing technology by which they have been, selfishly, controlling their sustainability. Of course, the issue of these institutions' willingness to accept that their mission, in addition to the traditional one (teaching and science), also involves the active participation in supporting the development of the society (third mission).

\section{The entrepreneurial being of sports - stepping towards the universities' third mission}

The physical activity of a modern man is a personal incentive also filled with social values and which has been increasingly functioning within a commercial environment. It has been given the outlines of an industry including a large number of interdependent factors, such as process, services, goods, space, people, information ... Physical exercise is an area of self-employment and a market in which the annual turnover realized in the United States amounts to about 215 billion dollars (according to the data from 2015), about 160 billion euros in the EU, or about 15 billion pounds in the UK. According to the United Nations' data, more than three percent of the world's annual wealth has been generated through this and the related industries. It is important to point out that the economic capacity of physical activity is not related only to elite sports, since, as the analyses have shown, there are much greater commercial opportunities in the area of children's, youth and mass sports as well as of the sports of persons with disabilities or special needs. Public - private partnership is a strategy that has led to the expanding of knowledge, greater employment and commercialization of human physical exercise.

Within the European framework, the key competences are defined as the educational outcomes, which include knowledge, skills and entrepreneurial attitudes. Knowledge is described as the ability to identify business opportunities. Skills proactively function within a project task (planning, organization, management, leadership, communication) both in individual and team work. Entrepreneurial attitudes are included in initiative, proactivity, independence and innovation, motivation and firm orientation in order to achieve goals. Knowledge and skills, expert competencies acquired through an interdisciplinary and multidisciplinary academic network and education (formal, informal) all the way to postdoctoral studies are required in order to participate in the creation of exercise as a product that will change the natural, social and economic environment of man.

Entrepreneurship has been imposed as a means of comprehensive education, which is why the terms such as „business university”, „entrepreneurial university” or "academic capitalism” have become widely known today. Universities have become centres of socio-economic development of the community. They are the ones that, through the affirmation of their third mission, meet the expectations of a narrower or wider community both in cultural and artistic sense, as well as in economic and socio-political development. The architecture of entrepreneurial university has been oriented towards a new strategy, management and business culture that will change the community and society (social entrepreneurship) (Vorley and Nelles, 2009). Entrepreneurial capacity and intended competencies are those that determine students as business individuals willing to undertake the initiatives that will lead to the changes in both business and living environment. The graduates' entrepreneurial activity should result in personal and social success, since an entrepreneur is someone who is willing and able to convert new ideas into a successful innovative value (Marburger, 2011).

An entrepreneur is characterized by a need for achievement, proactivity, innovation, creativity, leadership, as well as the skills of problem solving, planning, negotiating, persuasion, oral and written com- 
munication, listening ... (Paunović et al., 2012). Since his innovative and creative activities are realized in both economic and social environment (including sports) an entrepreneur is also characterized by social competence, broad interdisciplinary and multidisciplinary knowledge from the core and other scientific and practical fields of activity.

A significant part of the skills that characterize an entrepreneur have been acquired by his growing up through sports. Thus it has been confirmed that sports encourage: functioning in accordance with the rules; co-operation; solidarity; achievement, but also the development of one's character through determination, initiative, self-determination; creating, tolerating and functioning under stress and with a high degree of risk; setting up and solving problems; searching for the best solution; acting through a team and an organized network ... Today, in relation to the late $19^{\text {th }}$ and the early $20^{\text {th }}$ century, "Coubertin's athletes" are much more responsible towards themselves, perfection, virtuosity, or what the ancient Greeks called the arete, when the sport was reserved for the best (ariston) and well-raised ones (eleutherion), who were awarded physical and moral virtues (the nobility was expected to be kalos and agathos, handsome and kind). It may be concluded that an athlete and an entrepreneur have much in common, so that the intention of the business world to convert good athletes into entrepreneurs has been justified, i.e. the society's endeavour to acquire the values that will be affirmative for the work in the entrepreneurial environment through sports, starting from the earliest school age (Jevtić, 2014).

Education within entrepreneurship and sports have been considered today as a means of comprehensive education. In this sense, it is necessary and to clearly define a social entrepreneur who is a diligent, socially and ethically guided individual who searches for new opportunities and additional values for the community through the innovations that lead to effective public service practices and which promote the values of society (Brooks, 2007). In the literature, social entrepreneurship has been viewed as a multidimensional construct of entrepreneurial behaviour, which is realized with the goal of achieving a social mission. The realization of a social mission, and not the acquisition of personal wealth, is a criterion of social entrepreneurship that promotes environmental sustainability, social progress, non-profit organizations (Ratten, 2011b).

Social entrepreneurship is realized within non-profit sector, and it is the result of engaging human capital and strategies that change the community members, their environment and society itself (Kessene, 2005). It is placed between business and charity activities, and it stimulates problem solving through the affirmation of physical activity that leads to social inclusion, fight against social problems, environment preservation, health awareness, and the like. It starts with the identification of an existing problem, differentiating the methods of its solution, followed by a concept or draft solution, defining and ensuring resources, initiating entrepreneurial activity, completion and affirmation of tasks (Brooks, 2007).

The network that is envisaged in entrepreneurship, and which connects the actors of business initiative is the basis of the horizontal and vertical connection that already exists in the entity of sports. Consequently, this network can be the basis for social capital made up of individuals, associations, societies that, among other things, also aim at developing and utilizing the social aspect of physical exercise (Jevtić, 2014).

Sports for entrepreneurship is an interesting term and a concept that within the scope of its activity also has some "hidden networks" that are the result of the friendships developed through sports and which are additionally fostered through business and private life. Networks represent the existing social and sports capital that can be planned and used to develop the community and improve the lives of its members. In under- developed countries, it is obvious that the social capital of sports has not been used for the purpose of the society development, i.e. in developed countries, physical activity has been used for the development of social capital. The network, which is provided within sports, is connected to the networks of other professions and thus, they together strengthen social exchange. Universities and students' sports activity represent a perfect space for establishing the relationships that will be nurtured for private and business reasons.

\section{UNIVERSITIES' THIRD MISSION AND THE "PHYSICAL CULTURE" SCIENTIFIC JOURNAL}

In internationally recognized „sports sciences”, there is a gap of 17 years between the completion of research studies and their transfer into practice, and even then it has been noticed that this is only a partial transfer of the acquired knowledge and practice (Thoma et al, 2016). In the process of transferring 
new knowledge and practice, there are several steps that are necessary to be fulfilled, and in each of them, the scientific journal „Physical Culture” has the space and role for a new strategy and action in the direction towards the "natural knowledge" improvement and the enhancement of social values through culture, art and science included in physical exercise.

The discussion on the universities' third mission in the Serbian legislation, but primarily due to the affirmation of the value-based attributes of physical activity influencing the development of individuals and society, the issue of the „Physical Culture” journal, which, as the leading national journal in Serbia, covers the scientific field of sports and physical education, has been put forth. In the Impressum it has been stated that it is the official journal of the University of Belgrade, Faculty of Sport and Physical Education, which publishes papers in the field of sports, physical education and recreation, as well as in related biomedical, humanistic, social and natural sciences. The manifestations of physical culture (sports, physical education and recreation) included in the previous expression are, vulgarly, equated with (related) sciences. In regard to the confusedly specified goal and scope of activity, and as the response to the process of pre-evaluation for classifying into the scientific databases by Scopus it has been stated that the „Physical Culture” must have a clear and concise goal and scope of activity ... and not to accept the papers that are beyond the framework - scope of the Journal ..., as well as that the international visibility of the publications is low. As this visibility is valued on the basis of the references to the published works, and, according to Scopus, the measurement is performed in the area of sports science, it is necessary to re-examine the goal and mission of the Journal in order to clearly define its scope of activity. Therefore, in order to introduce the „Physical Culture” into international databases, the term „Physical Education and Sport” science which has been administratively given is questionable. The title of the journal "Physical Culture" is not problematic, in addition, in the Thomson-Reuters' response, and on request to include the Journal in their database, it has been indicated that "physical culture is a very competitive field of research". Therefore, the search for the Journal's paradigm, based on national and international recognition and evaluation, should be initiated by the changes which are in the first step introduced by the publisher (issues of affiliation, publisher itself, defining a clear mission, goal and scientific scope of activity ...). This should be followed by the steps tak- en by the editorial (editorial board ...), editor-in-chief (editors of fields and areas, reviewers ...), authors' thematic frames. The issues of design, social networking strategy, connections with conferences, national and international professional, scientific and sports organization are of equal importance.... Of course, all of this is also determined by the budget! However, these and other goals are not achieved by stating that it is an official scientific journal of the University of Belgrade, but primarily by the need to engage the "whole" of the scientific and professional community in Serbia and in the region that gravitate toward this Journal.

\section{The "Physical Culture" journal for professions and occupations involved in physical exercise}

By directing the course of this discussion from the point of understanding the relationship between the science of Sport and Physical Education and the third mission of the university, we can observe a number of doubts, out of which, for the purpose of this discussion on the mission of the scientific journal „Physical Culture" and a new editorial paradigm, the following should be considered: 1 . the reality of higher education in the field of SSPE is the existence of state and privately-owned faculties, and many of the latter, within their program orientations, have opted for the study of the managerial, but not the leadership and scientific aspects of physical activity-exercise; 2 . the "sensitivity" of the institutions founded by the state decree from the period of socialism to the issues of the continuum of human physical activity is questionable as well as its capacity to equally determine the cultural and economic values in the $21^{\text {st }}$ century; 3 . the question is whether the employed, and even the graduates themselves of both groups of the institutions really understand entrepreneurship, the affirmation of initiatives, innovations and business skills in the area of sports, physical education and recreation; 4. it is difficult to determine whether and to what extent it is a step forward that would affirm the ontological and axiological continuum of the scientific field, and which has been developed today, as it was the case in the past, from its cultural to its economic reality, from subjective to objective values, from sports to commercial and business function of sports organizations (Figure 3, presented through an example of sports). 


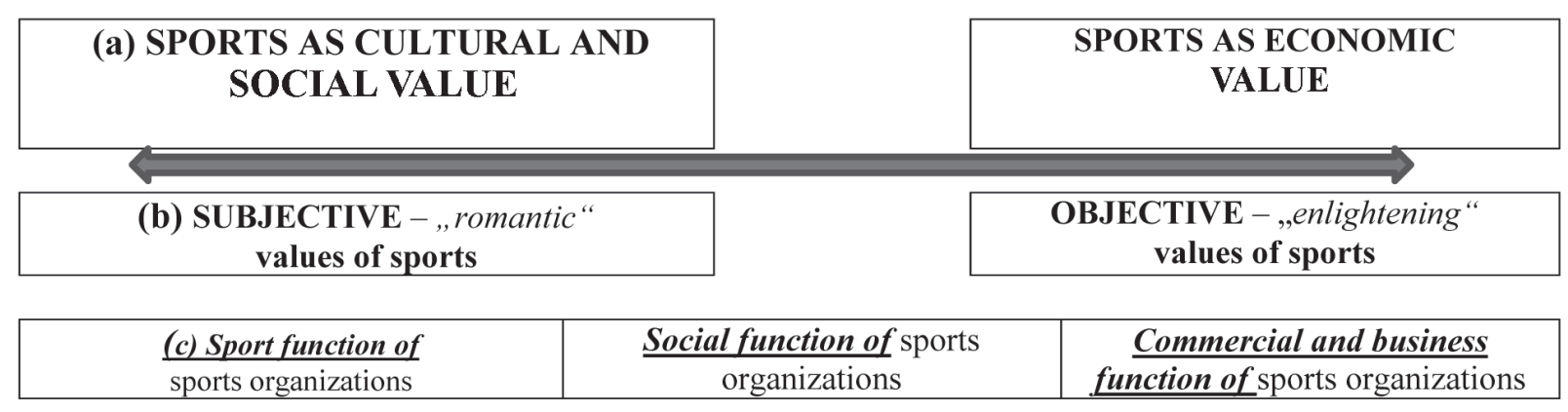

Figure 3. Ontological (a) and axiological continuum (b) of sports, from sport to business function of sports organizations (c) (Jevtic, 2014)

The analysis of accreditation applications would suggest the presence of the statements by both groups of the faculties regarding the similarity in planning and program documents in relation to at least two foreign - European higher education institutions. The program similarity raises the issue of educational outcomes and especially whether the national faculties' curriculums lead to the professional staff and their competences to develop Serbian society, industry and technology of sports - physical education - physical recreation ... It should be emphasized that educational outcomes are precisely measured statements included in the mission by which the leading universities in the world ensure the external assessment and evaluation of curriculums and institutions and direct the prosperity of the profession, science, society and graduate students. Outcomes result in the professionals who are educated, trained and skilled and characterized by the competences required for demanding and dispersed labour market. Accordingly, new ques- tions are being put forward, such as: what is the ratio of educational outcomes and the labour market; has the education for living and working within capitalist social order been developed in Serbia; do the domestic faculties educate the professionals who are capable of becoming the leaders in their expertise and society or are the professional hopes of the graduate students directed towards the market dominated by clearly defined and profiled professions or is it just a utopia that restrains them within the previous and outdated conditions? The answers to these or to any of the above mentioned concerns and questions require consideration on what extent the staff, profession and its scientific field have been developed and emancipated for the tasks and missions of higher education in the $21^{\text {st }}$ century! The answers to the previous and many other questions may be drawn from the vector analysis of the value-based changes of society according to which the paradigm of the study of human physical activity (sports) has been changing (Figure 4).

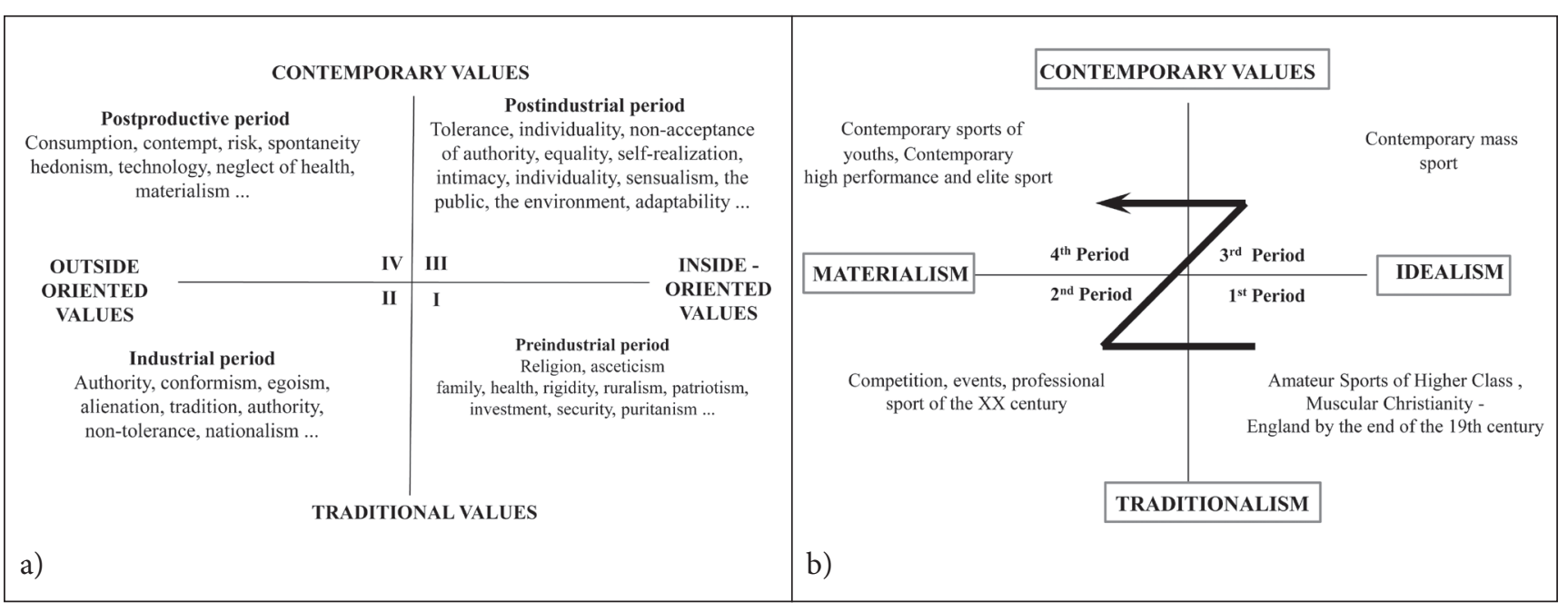

Figure 4. Periods of social development (a) and the values of sport according to the periods of its development (b) (modified according to: Jarvie, 2006, Brevik, G.- unpublished conference presentation ) 
Basic search of the indexed databases has shown that a small number of domestic authors deal with physical activity, entrepreneurship in sports, entrepreneurial university and - or the universities' third mission (Jevtić, 2014). The implications may be foreseen, suggesting a small number of those academics who will, upon acquiring their university degrees, pursue a business initiative or a job position in an environment that „escapes” the state as an employer. The subject matter of the national journal „Physical Culture" and its services (blog) must include what the profession should discuss and deal with, toward what it should tend, explain, study ... in which direction it should be changed-emancipated itself... By analysing the Figure 5, it is easy to determine that the system of physical activity (physical education, sport, physical recreation, employees, volunteers, audience ...) in Serbia is located in the first or "bureaucratic quadrant" - with a strong influence of the state (A) so that the path to the entrepreneurial configuration of both the system of sports and the university itself (Figure 1) should also lead through the scientific journal „Physical Culture”.

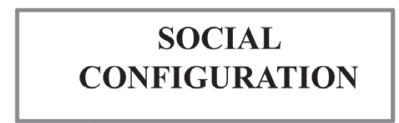

Program orientation, Participation, Cultural values, Long-term investments Capacity building Trust, Community development...
Decentralization, Public sector as a partner in achieving change

Volunteer engagement and mass sport Short-term goals, Orientation toward the process, service... Innovation, expansion, adaptability Monitoring and evaluating performance

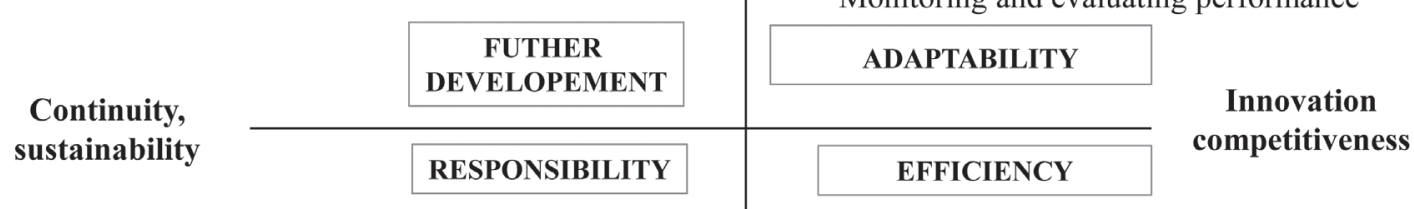

The strong influence of state on sport, Governance orientation and monitoring, Mistrust, prejudice, abuse, The question of respect of Sport Specificity and Autonomy

BUREAUCRATIC CONFIGURATION
Management by Private sector

Orientation to efficiency

Short-term goals

Audit of programs

Contractual obligations of the parties

\section{ENTREPRENEUR}

CONFIGURATION

Centralization in decision-making and specific requirements of the state

Figure 5. Configuration and evaluation of the national systems of physical activity - sports in the EU (Vocasport (2005).

\section{CONCLUSION}

I Modern sport, physical education and physical recreation have been also observed through an additional value, which is achieved through the application of knowledge and technology in the planning, designing and affirmation of the effects of physical exercise directed towards the contemporary way of life, the needs of an indi- vidual and society. The contemporary product of these manifestations of physical culture leads to higher quality of life, stimulates life (social and natural) environment, influences the creation of new job positions, creates new products and working profiles .... (business environment).

II The knowledge necessary to develop physical exercise further, thus influencing individuals and society, constitutes an intertwined network 
of theoretical and empirical facts, including those related to education, health, communication, art, culture, ecology, axiology of nature - culture of physical exercise, ecology-related technologies, business, and international relations and policies as well. The research subject matter also includes economic issues (economics, marketing, management, planning). The research issues within sports sciences themselves have been intensely elaborated (sports, health, doping, biomechanics, training technology ...), sociological issues of physical activity (social aspects, job positions, social reform, democratization, politics, parliamentarism, volunteers ...) as well as historical and political, socio-cultural, philosophical and educational fields. The corpus of interdisciplinary and multidisciplinary knowledge and current practice may form a framework for defining the area of the „Physical Culture" scientific journal within the science, culture and art of physical activity!

III Universities have become centres of socio-economic development of the community. They are the ones that, through the affirmation of their third mission, meet the expectations of a narrower and wider community both in cultural and artistic sense as well as in economic and socio-political development. The architecture of „entrepreneurial” university is oriented towards a new strategy, management and business culture that changes the community and society (social entrepreneurship). At the universities in Serbia, the being, knowledge, values, practices, etc. of physical education, sports and physical recreation have been studied for eighty years, and now it is only necessary to organize the transfer towards individuals, community and prosperity of the society.

IV Full affirmation of „entrepreneurial” university has been also enabled by the realization of the universities' third mission. In order to develop and direct innovations towards society efficiently and effectively, it is necessary to establish a technology transfer office. Publishing activity, and therefore scientific journals, conference proceedings, technical and technological solutions, etc. are just some of the means that can improve the transfer of knowledge and technology from the univer- sity's departments to the community and society. Technology transfer offices are faculty structures through which teachers, associates, researchers and students communicate with the "actors" outside the university. The Law on Higher Education in Serbia recognizes technological parks, incubators, departments for professional development and continuous education ... These or similar business solutions and their orientation in the field of the science of Sport and Physical Education will be possible only by accepting the culture of changes, organizational and productive values ... leading to the emancipation of the respective faculty communities and their transfer into a higher level of university development.

$\mathrm{V}$ In the process of transferring new knowledge and practice, there are several steps that are necessary to be fulfilled, and in each of them, the "Physical Culture” scientific journal has its position and role in a new strategy and activity towards the improvement of "natural knowledge" and value-based enhancement of society through culture, art and science included in physical exercise.

VI The „Physical Culture” journal, in the context of the affirmation of the universities' third mission and the transfer of innovations towards society and practice, can reach heterogeneous users of knowledge in the field of human physical exercise. The journal, in addition to the results of basic and applied research, should promote the knowledge of importance for society, community, entrepreneurs in physical exercise.... Cognitive and motor skills make the users' expectations, and therefore the transfer process, more complex. For this purpose, social media are one of the means of knowledge dissemination, but also of starting a creative dialogue between the actors of the profession and practice of the sciences related to physical education, sports and physical recreation. Creating the "Physical Culture" journal blog on social networks would enable the broadcast of video recordings as well as the establishing of a two-way communication channel between publishers, editors, authors, reviewers and users of knowledge. 


\section{REFERENCES}

1. Brevik, G. Core values in athletics. Unpublished conference presentation. in pp.

2. Biegank, K.A., Huberty, L.L. (2015). Analyzing the organizational structure of the community engagement activities of professional sport teams in the United States. Int. J. of Humanities and Social Science Invention 4:8:26-40.

3. Brooks, C.A. (2007). Social Entrepreneurship: A modern approach to social value creation. Prentice Hall.

4. Bruyant, J.A.P. (2000). Defining the fields of research in entrepreneurship. J of Business Venturing, 16:165-180.

5. Clancy, P., Dill, D.D. (2008). The Research Mission ot the University. Policy reforms and institutional response. Rotterdam, Boston, Taipei: Sense Publisher.

6. Domazet, D., Adižes, A. (2014). Primen koncepta preduzetničkog - inovativnog univerziteta - put ka stvaranju nove idustrije znanja i razvoja savremenog otvorenog univerziteta. [Applying the concept of enterpreneurial and innovative university - A pathway in creating a new knowledge - Based indystry in Serbia and development of modern and open university, In Serbian]. Tehnologija, kultura $i$ razvoj, Zbornik radova 21: 23-38. Beograd: Udruženje Tehnologija i razvoj.

7. Hagen S. (2008). From tech transfer to knowledge exchange: European universities in the marketplace. In The University in the Market, Edited by: Engwall, L and Weaire, D. London: Portland Press.

8. Jarvie, G. (2006). Sport, Culture and Society. London, New York: Routledge.

9. Jevtić, B. (2014) Sport i preduzetništvo. [Sport and Enterpreneurship, In Serbian] Tehnologija, kultura $i$ razvoj, Zbornik radova 21: 122-135. Beograd: Udruženje Tehnologija i razvoj.

10. Jevtić,B., Radojević,J., Juhas, I., Ropret, R. (Ur) Dečiji sport od prakse do akademske oblasti. [Children's sport from practice to academic area, In Serbian] . Beograd: Fakultet sporta i fizičkog vaspitanja.

11. Kesenne, S. (2005). Do we need an Economic impact study or a Coast-Benefit-Analysis of a Sport Event? Europ. Sport Manag. Quarterly, 5:2: 133-142.

12. Kurbatov, V.S. (2015). The mission of contemporary university through the lense of time and space. Науковии вісник. Серія Філософія, 44: 176-184.
13. Marburger III, H.J. (2011). Science, technology and innovation in a $21^{\text {st }}$ century context. Policy Sci,44: 209.

14. McDonald, M. A. (2009). Practicing community engaged research. Retrieved November 26, 2011, from https://www.dtmi.duke.edu/about-us/organization/duke-center-forcommunity-research/ Resources/comm-engaged-research.pdf/

15. Paunović, B., Nikolić, M., Stosković, M. (2012). Importance of entrepreneurship education for economic development of Serbia. In Radović-Marković, M, Grozdanić, R., Krumov, K Ed: Employment, education and enterpreneurship. The first international conference Vol. 3. Beograd: Faculty of Business Economics and Entrepreneurship.

16. Pupovac, D. (2014). Obrazovanje - laka industrija ili kovčeg panaceje država jugoistočne evrope [Education - Light industry or Panacea coffin of South-East European State, In Croatian]. Tehnologija, kultura, razvoj, Zbornik radova 21:7990. Beograd: Udruženje Tehnologija i razvoj.

17. Ratten, V. (2011a). Social entrepreneurship and innovation in sports. Int. Jour. for Social Entrepreneurship and Innovation 1(1)42-54.

18. Ratten, V. (2011b). Sport-based entrepreneurship: toward a new theory of entrepreneurship and sport management. In. Entrep. Manag. J, 7: 57-69.

19. Scott, C.J. (2006 ). The mission of the University: Medieval to postmodern transformations. J. of Higher Education 77:1-39.

20. Smith, C.T.A., Westerbeek, M.H. (2007). Sport as a vehicle for deploying corporate social responsibility. The J. of Corporate Citizenship 25: 5-12.

21. Talbot, M., Stringer, C., Neal, L et 1 (2005). Community sport - Oral and written evidence. London: House of Commons.

22. Thoma, J., Walker, TW, Miler.S, Cobb,A., Thomas, S.J.(2016). The Olympic legacy: Journal metric in sports medicine and dentistry. J. Int.Soc. Prevent Communit Dent 6:501-508.

23. Vocaport (2004). Vocational education and training in the field of sport in the European Union: situation, trends and outlook. EOSA, Lio

24. Vorley, T., Nelles, J. (2009). Building Entrepreneurial Architectures: a conceptual interpretation of the Third Mission. Policy Futures in Education 7 - 3- 284-96. 


\title{
WISSENSCHAFTLICHE ZEITSCHRIFT „KÖRPERKULTUR“ IN DER MISSION ZUR ENTWICKLUNG DER WISSENSCHAFTLICHEN UND GESELLSCHAFTLICHEN GEMEINDE
}

\begin{abstract}
Zusammenfassung
Moderne Universitäten übernehmen die Rolle der Achse der Wirtschaft, die auf Wissen und innovativer Politik basiert. Sie beschäftigen sich mit gesellschaftlichen Problemen, vor allem mit dem Bedürfnis nach allgemeiner Entwicklung, sowie mit Problemen, die vernachlässigt oder von seiten der Verwaltungsdistanzen nicht gelöst werden. In Serbien wird ein Projekt realisiert, das außer zwei schon existierenden Missionen (Unterricht und Forschung) eine dritte Mission der Universitäten entwickeln und implementieren soll, die aus drei Säulen besteht: Wissenstransfer - Technologien und Innovationen; kontinuierliches Lernen; sowie Aneignung und Anwendung gesellschaftlich verantwortlichen Verhaltens von seiten der serbischen Universitäten. Die Veränderung zu einer modernen, unternehmerischen Universität sollen auch Veränderungen der Mission der wissenschaftlichen Zeitschriften begleiten, weil der gemeinsame Nenner von Schöpfern und Disseminatoren des Wissens die Prosperität der Wissenschaft und der Gesellschaft ist, die auf Innovationen gründet. Gemäß all dem Angeführten bezieht sich der Gegenstand dieser Arbeit auf die vorausgesetzte Rolle der Universität in der Entwicklung der Gemeinde bzw. auf die Kapazität der wissenschaftlichen Zeitschrift „Körperkultur“, ein Intermedium zwischen Unterricht, wissenschaftlicher und gesellschaftlicher Mission der Wissenschaft „Körperkultur und Sport“ darzustellen.
\end{abstract}

Schlüsselwörter: DRITTE MISSION DER UNIVERSITÄT / UNTERNEHMERTUM / KÖRPERLICHE AKTIVITÄT / WISSENSCHAFTLICHE ZEITSCHRIFT / SERBIEN

Received: 01. 11. 2017.

Accepted: 02.12.2017. 


\title{
НАУЧНИ ЧАСОПИС „ФИЗИЧКА КУЛТУРА“У МИСИЈИ РАЗВОЈА НАУЧНЕ И ДРУШТВЕНЕ ЗАЈЕДНИЦЕ
}

\author{
Бранислав Јевтић \\ Универзитет у Београду, Факултет спорта и физичког васпитања, Србија
}

\begin{abstract}
САЖЕТАК
Савремени универзитети су окосница економије засноване на знању и иновативној политици. Они се баве проблемима друштва, пре свега потребом општег развоја, као и проблемима који су занемарени или нису „испуњени“ од јавних власти. У Србији се реализује пројекат који, осим постојеће две мисије (настава и истраживање), треба да развије и имплементира трећу мисију универзитета, коју чине три стуба развоја, и то: трансфер знања - технологија и иновације, континуирано учење, као и стицање и примена друштвено одговорног понашања од стране српских универзитета. След промена до савремено предузетничког универзитета треба да прате и промене мисије научних часописа, јер, заједнички именитељ стваралаца и десеминатора знања је просперитет науке и друштва заснованог на иновацијама. Сходно наведеном, предмет овог рада се односи на претпостављену улогу универзитета у развоју заједнице, односно на капацитет научног часописа „Физика култура“ - да буде интермедијаран између наставне, научне и друштвене мисије науке „Физичко васпитање и спорт“.
\end{abstract}

КљУчне речи: ТРЕЋА МИСИЈА УНИВЕРЗИТЕТА / ПРЕДУЗЕТНИШТВО / ФИЗИЧКА АКТИВНОСТ / НАУЧНИ ЧАСОПИС / СРБИЈА

\section{УВОД}

Високошколско образовање описује и детерминише наставна и истраживачка делатност, које су, зависно од периода у развоју универзитета, биле у корист оснивача (цркве, владара, владе...) и власника. Историја нас учи да је мисија универзитета динамична и променљива, да је резултат филозофских идеја, образовне политике, културе друштва, као и развоја самог универзитета као установе (Sccot, 2009). Мисија универзитета се успоставља и око циљева, као што су развој демократије, прогрес, рата и мира, хуманости.... Ипак, она је увек у функцији добробити друштва (Слика 1.).

Сагледавајући развој високог образовања кроз временску димензију, уочава се „такмичење“ у доминацији између наставне и научне делатности. У последњих деведесет година стреми се афирмацији његове „треће мисије“ која је усмерена развоју заједнице и друштва. Универзитети у САД су још почетком тридесетих година 20. века исказали своју аспирацију према „универзитетској тријади“, односно потреби да буду институције у којима је садржано јединство наставе, истраживања и јавног утицаја и друштвеног значаја (Clancy and Dill, 2009). Стога, када се сагледа 930 година универзитетског образовања, уочавају се два међузависна процеса, од којих је први повезан са националном aсйирацијом (мисија у заштити националне културе и добробити заједнице), док се други односи на иниеернационалну асиичацију (глобални утицај и међународно рангирање) (Kurbatov, 2015). Сходно наведеном, предмет овог рада се односи на претпостављену улогу универзитета у развоју заједнице, односно на капацитет научног часописа „Физика култура“ да буде интермедијаран између наставне, научне и друштвене мисије науке „Физичко васпитање и спорт“. 


\section{III Период: Аутономија наставе и истраживања - јавна функција универзитета}

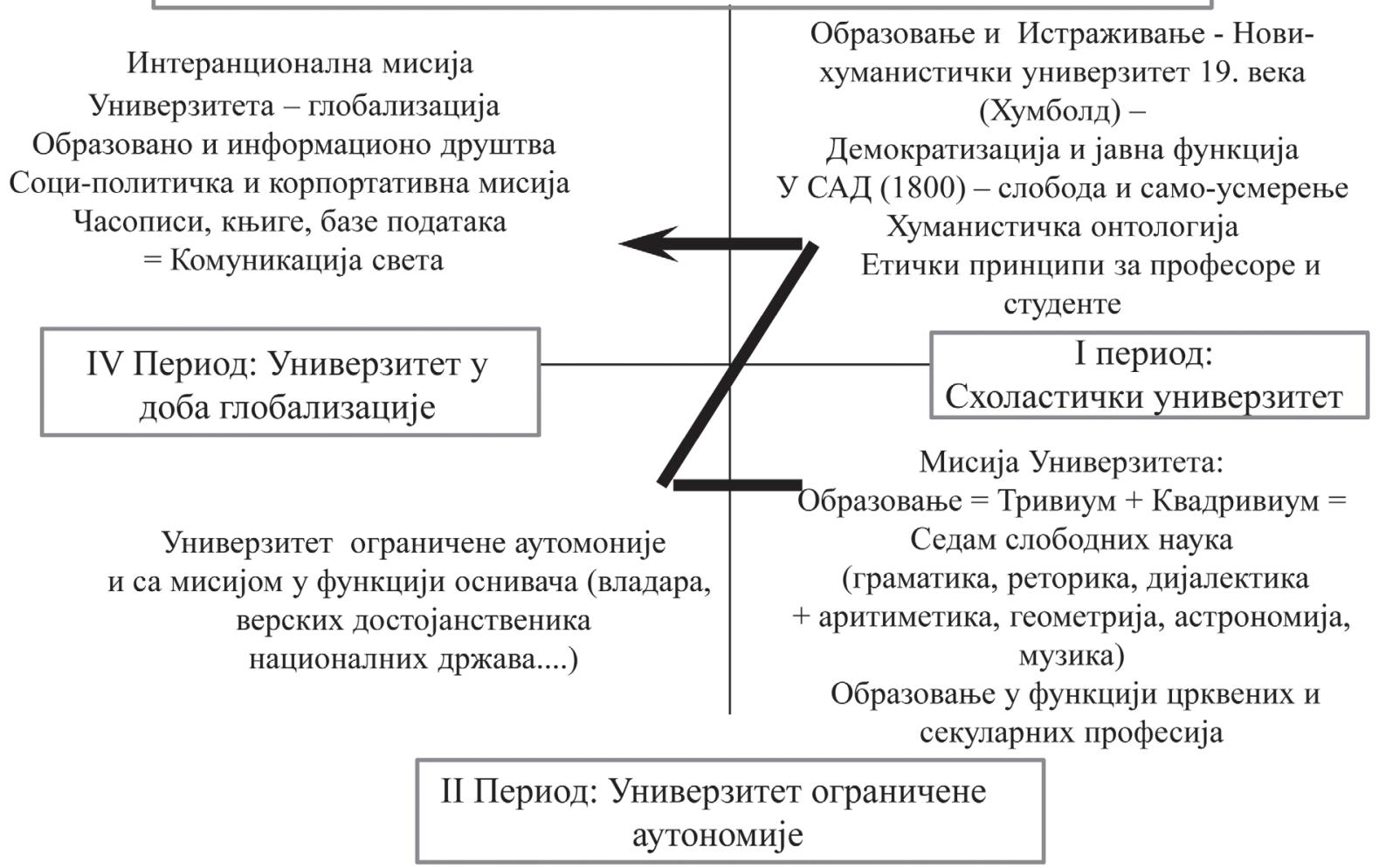

Слика 1. Периоди развоја и динамика мисије универзитета (приказ на основу Clancy and Dill 2009)

\section{ИНОВАЦИЈЕ И ТРЕЋА МИСИЈА УНИВЕРЗИТЕТА}

Карактеристика савременог друштва је општи развој на бази иницијатива, креативности и иновација. Тако се и капацитет једног друштва мери економским развојем, унутар кога доминира степен иновативности. Европски индекс иновација за 2017. годину, Србију сврстава у групу држава „Умерени иноватори“. Овој групи претходе групе „Лидери у иновацијама“ (Швајцарска...) и „Јаки иноватори“ (Словенија...). Са индексом иновација од 64,2, Србија заузима 28. место, иза ње је осам земаља, од којих је шест чланица ЕУ (ЕУ индекс 2017).

У Закону о високом образовању Србије из 2017, у члану 59, став три, преписано из Закона из 2005. године, дефинисано је, да у циљу комерцијализације резултата научноистраживачког или уметничког рада, универзитет-факултети могу оснивати научне институте, иновационе центре, центре изузетних вредности, центре за трансфер технологија, пословно-технолошки инкубатор, научно-технолошки инкубатор, научно технолошки парк и друге организације за обављање иновационе делатности и пружање инфраструктурне подршке за развој иновација и комерцијализацију резултата истраживања. Овим документом није препозната друштвена оправданост и искоришћеност резултата научноистраживачког рада, али није извршена ни спецификација смисла и значења појма иновације. Ипак, треба веровати и надати се да је законописац подразумевао не само иновације којима ће се подстицати комерцијализација резултата, економски развој и већа финансијска самосталност самих факултета, већ, и пре свега да је претпоставио да се иновације односе и на друштвени развој, као и на развој предузетничког капацитета и компетенција студената. На слици 2 приказана је „Мисија савременог иновационог универзитета“, коју је аутор модификовао имајући у виду „трећу мисију“универзитета. 


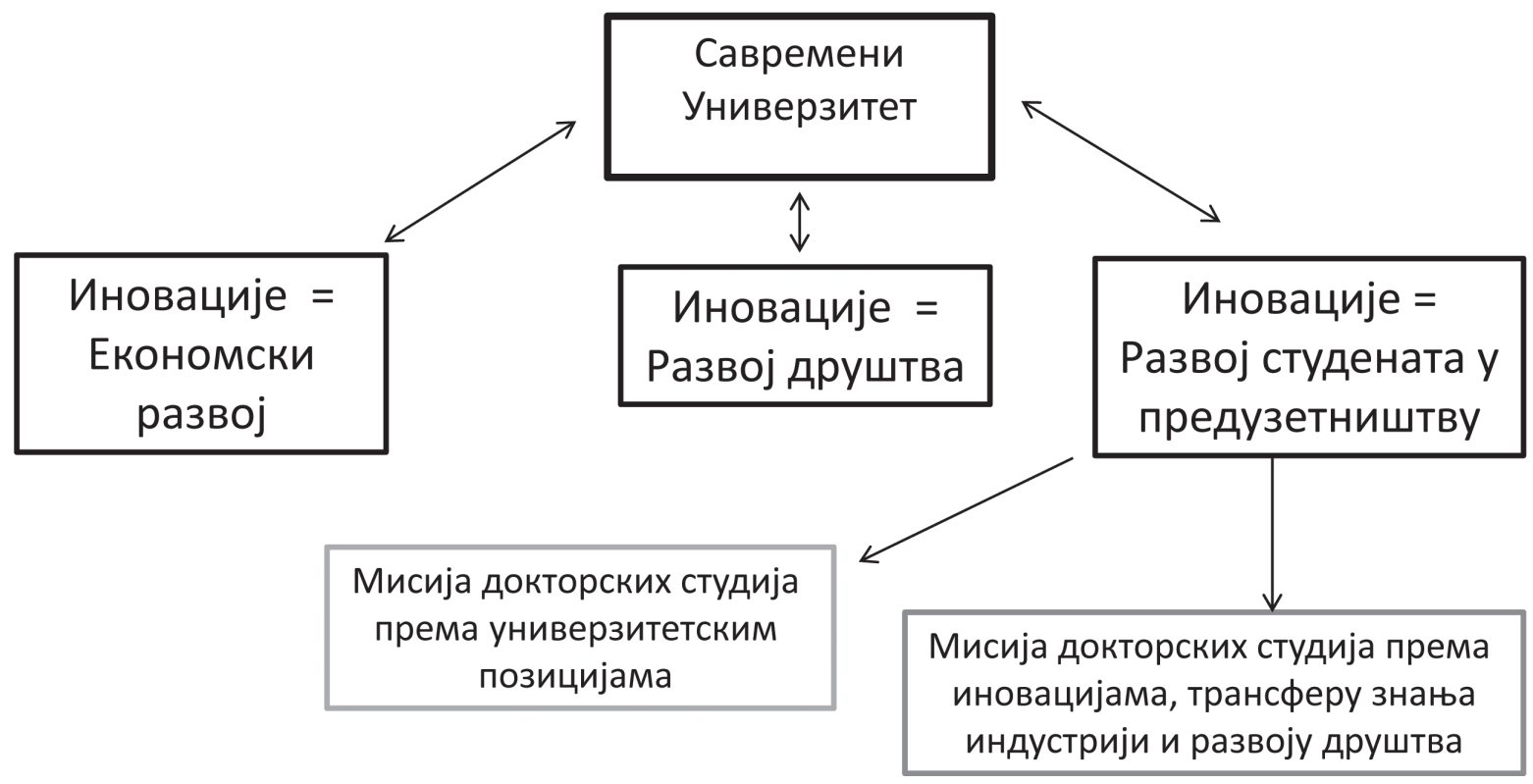

Слика 2. Мисија савременог - иновационог универзитета (модификовано према Clancy and Dill, 2009)

И површним увидом у законе који су до 2005. године детерминисали високо образовање у Србији, уочава се постојање великог броја чланова који су регулисали наставну делатност и матичност факултета за поједине научне области. Закони од 2005. године раскидају са уређењем наставне делатности универзитета и факултета (прва мисија универзитета). Уместо разраде „прве мисије“ универзитета, законописац је унео чланове којима се формирају и описују функционисање тела задужених за обезбеђење квалитета, акредитацију, управљање токовима високошколског образовања... Данас, након усвајања Закона о високом образовању (2017) „подржављена“ су сва та тела, чиме је директно угрожен аутономни развој високог образовања. Ушло се у ново спорење државе и академске заједнице, Закон су оспорили универзитети, Савет у високом образовању, Комисија за акредитацију и проверу квалитета, Српска академија наука и бројни професори и истраживачи. „Закон умањује достигнуће аутономије образовних установа, због чега, пре свих, Српска академија наука и уметности тражи да се новоусвојени закон измени или донесе нови“. Одговора друге стране - државе нема, она очекује да се поступи по усвојеном закону. У наредних шест месеци, у тишини, сагласни у одрицању од еманципације све три мисије, одвијаће се усвајања посебних докумената (статута), како на универзитетима, тако и факултетима и научним институтима. Тако ће академска заједница Србије, на крају друге декаде 21. века, добровољно гласати за статуте којима ће се одрећи не само аутономије, већ и интеграције и децентрализације високог образовања. Држава, као власник универзитета je, као и некада владари, поново носилац високог образовања. Добила је одлучујуће место, не само у простору оснивања, организације и финансирања, већ, и пре свега у делу процеса акредитације и дозволе за рад сваке појединачне високошколске установе. Овај circulus vitiosus између креатора и корисника закона одражава стварност Србије 21. века којом се биће њеног високошколског образовања враћа у други период развоја универзитета (Слика 1)! Како до слободног и аутономног универзитета, како и када у наредне периоде развоја којим доминира универзитет који доноси прогрес заједници - друштву које га финансира, остаће непознаница за овог аутора и генерације наставника, сарадника и истраживача на универзитетима у Србији?

\section{Предузетничке интенције и „трећа мисија“ универзитета}

„Анализа програма по којима се реализује настава на универзитетима у Србији указује да су они застарели, да заостају за савременим по- 
требама и изазовима друштва, да профили који се школују, у добром делу нису конзистентни са потребама друштва. Истраживања се воде знатижељом и интересом истраживача и професора а мањим делом потребом друштва. Научна публицистика, је основни критеријум за избор наставника, који је главни подстицајни фактор истраживања за библиотеке и развој каријере уместо истраживања за решавање потребе друштва“ (Домазет, 2014). Са друге стране, Пупавац (2014) који високо образовање сагледава као највећи успех социјалне државе, наводи да у Хрватској годишње дипломира 36000 студената, у Србији 45000 , а у Босни и Херцеговини 18000. Додаје да се мало тога променило у наставној и научној индустрији овог региона у односу на времена када је Аристотел подучавао на Ликеју у Атини, као и да ови системи образују студенте за традиционалне и непросперитетне послове, али не и за економију и друштвени прогрес заснован на иновацијама и знањима (Bubble образовање).

Док време на географским просторима из анализа Домазета (2014) и Пуповца (2014) као да стоји или иде уназад, дотле се, ововременски универзитети прилагођавају корпоративној мисији и све више се препознају као предузетничке институције унутар којих се интенционо обављају и публикују резултати истраживања од значаја за прогрес - нову економску теорију и праксу (кроз економско предузетништво) и друштвену стварност (кроз друштвено предузетништво) (Brooks, 2007). Иновативну и предузетничку мисију, како у економском, тако и у друштвеном предузетништву, прати промена финансирања истраживања од традиционалног - линеарног модела ка националном-иновативном моделу који је први развијен у Скандинавији, и који у себи садржи концепт примене науке у функцију одрживог развоја друштва (Clancy and Dill, 2009).

Савремени универзитети постају окосница економије засноване на знању и иновативној политици (Hagen, 2008). Они се баве проблемима друштва, пре свега потребама његовог општег развоја, као и оним проблемима који су „занемарени или нису испуњени“ од јавних власти и приватног сектора (Ratten, 2011a). Пут којим се стиже до ових циљева националног и наднационалног универзитетског образовања подразумева (Clancy and Dill, 2009): (и) искораке у настави и њеној организацији, (и) увећање квалитета истраживања и њихову повезаност са наставом, индустријом и друштвом (пословна страна), (и) нагласак на квалитетној евалуацији (нормитивно-објективна страна резултата наставе и истраживања), (и) организација трансфера знања, (и) примена знања и план друштвене активности (друштвено-корисна страна знања)...

У стратегији приступа „предузетничком универзитету“ вреднују се излазни, а не улазни критеријуми, како се то ради у Србији (буџет, број студената, број наставника, величина зграда, библиотечки фонд и слично). Излазни критеријуми, као што су број иновација, број запослених дипломаца, друштвена оправданост програма, наставе и истраживања, економска оправданост и бенефити, пренос знања у пословно окружење, патенти, награде дипломцима, организациона целисходност, број новооснованих пословних јединица...., само су неки од критеријума успешног универзитета и основа за њихово рангирање. Данас је тешко замислити универзитет који успева да опстане преносом тацитног (неструктурисаног) знања. У том правцу, нарочито у сачињавању стратегије за нову истраживачку и друштвену парадигму факултета из простора наука физичког васпитања и спорта, континууму научих истраживања, који се протеже од базичних до апликативних истраживања, треба додати и трагање за смислом друштвеног прогреса и методологију „ангажованих истраживања“" (community engage research) којима се тежи; у спровођењу иновација и закључака истраживања треба укључити и не-специјалисте као партнере. Ово је вид истраживања и начин како наука комуницира са друштвеном заједницом (McDonald, 2011).

След промена од традиционалног Хуболтовог приступа до савременог - предузетничког универзитета мора да прати и промена мисије научних часописа, јер, заједнички именитељ стваралаца и десеминатора знања мора бити дуалност, а то је просперитет науке и друштва заснованог на иновацијама. На том путу, и са тим циљем се одвијају промене исхода докторских студија, које од сврхе обезбеђења научног подмлатка за универзитетске послове (настава и наука), тежи ка докторандима као лидерима истраживања за програме развоја индустрије и самог друштва (Слика 2) (Sccot, 2009). Универзитети и факултети који целовито сагледавају своју друштвену мисију, као први корак у реализацији своје треће мисије, као 
њен најкритичнији део, формирају канцеларије за трансфер знања, а са циљем повезивања ствараоца и корисника знања. На том путу, као једно од средстава трансфера иновација треба препознати и капацитет научних часописа. У Србији, у простору наука физичког васпитања и спорта, а међу њима је и водећи национални часопис „Физичка култура“.

На овом месту, а као подршка расправи о трећој мисији универзитета, треба навести и учешће Србије у међународном конзорцијуму у реализацији пројекта „Институционални оквир за развој треће мисије универзитета у Србији“. Реализација овог пројекта је започета 15. октобра 2015. године и треба да буде окончана у октобру 2018. године. Пројекат се кофинансира у оквиру ЕРАСМУС ПЛУС програма Европске уније, а реализује га конзорцијум од 18 партнера унутар кога је пет европских универзитета и шест универзитета из Србије. Примарни циљ пројекта је да се на универзитетима у Србији, осим постојеће две мисије које се односе на образовање и истраживања, развије и имплементира трећа мисија (Развој друштва и заједнице) коју чине три стуба развоja, и то: трансфер знања - технологија и иновациje, континуирано учење, као и стицање и примена друштвено одговорног понашања од стране српских универзитета.

\section{НАУКА „ФИЗИЧКО ВАСПИТАҢЕ И СПОРТ“ И ТРЕТА МИСИЈА УНИВЕРЗИТЕТА}

Физичко васпитање, спорт и физичка рекреација имају значајну друштвену функцију и велику одговорност. Анализа спроведена у Аустралији је показала велики капацитет физичког васпитања и спорта у простору друштвено одговорног деловања, али је, уједно одредила и чиниоце којима је могуће деловати у простору просперитета заједнице. Смит и Вестербек (2007) су утврдили „јаку комуникациону моћ“" физичке активности путем које је могуће доћи до сваког члана заједнице. Као ефекат тога, физичка активност је прво средство у „Апелу младима“ за њихово одрастање у породици, спорту, образовању, култури, заједници (учесници, фанови). „Позитивни здравствени утицај“ је идеална платформа за активност и свесност по питању и проблему здравља сваког чла- на заједнице. Следе чиниоци физичке активности којима се подстиче: (и) „интеракција заједнице“, како у функционалном смислу, тако и у његовој демократизацији, тежњи ка миру, социјалној кохезији, радости..., (и) „свесност о одрживости“ и нулта толеранција за нарушавање животне средине; (и) „културна идентификација и интеграција“; (и) „непосредна добробит од задовољства“ која као таква инспирише чланове заједнице да вежठају, подржавају и високо вреднују физичку активност. До сличних закључака су дошли аутори у примеру одговорног понашања клубова унутар професионалног спорта у САД (Bieganek, Huber, 2015). О вези физичког васпитања, спорта и физичке рекреације у односу на бенефите британског друштва, развијена је, може се рећи, јединствена пракса, за коју се научним аргументима и примерима добре праксе борила Маргарет Талбот (2002). Екстензивну студију о бенефитима физичке активности на правилно одрастање и интегрални развој детета доноси научна монографија „Дечији спорт од праксе до академске области“, групе аутора са Факултета спорта и физичког васпитања у Београду (Jevtic et al, 2011).

Данашње поимање високог образовања у Сpбији, самим тиме и академског деловања универзитетских јединица (факултета) у делу науке „Физичко васпитање и спорт“ (НФВС), доминантно се односи на наставу и науку. Анализа мисије, неких од факултета из области НФВС, упућује на изостанак оријентације према реализацији треће мисије универзитета, оној која је универзитете широм света учинила успешним и која је задужена за социјални, економски и културни развој заједнице којој универзитет припада (Vorley, Nellies, 2009). Тако, Факултет спорта и физичког васпитања своју мисију преузима из мисије Универзитета у Београду, чиме, хотимично или не, одустаје од своје особености и идентитета који је грађен осамдесет година, током којих су „освојене вредности“ и остварени резултати на понос високошколском образовању, друштву Србије па и самом Универзитету у Београду. На званичној интернет презентацији се наводи да је мисија овог Факултета „Омогућавање највиших академских стандарда и стицање знања и вештина у складу са потребама друштва и пројектованим националним развојем, као и трајно опредељење унапређењу квалитета високог образовања и укључивања у 
јединствен европски простор високог образовања“. Очито је да овом исказу недостаје интерна перцепција струке којој припада, сврха постојања, односно, не види се допринос студентима, професији, друштвеној заједници, наредним генерацијама... (екстерна мисија). Факултети у Нишу и Приштини (измештен у Лепосавићу), своју мисију виде истоветно, и то као „Осигурање једне од водећих позиција у школовању кадрова за спорт, физичко васпитање и рекреацију..... Тешко је утврдити место и улогу факултета у једном друштву када се њихова мисија поставља као национално такмичење ко ће бити бољи у школовању кадрова. Тешко је (ус) тврдити да су наведени факултети свесни своје „вишедимензионалне функције“ у простору културе, уметности, науке и економије друштва коме припадају, а које плаћа њихово функционисање. Наведени искази мисије отварају питање да ли су ове факултетске јединице застареле или савремене у исходима и сврсисходности постојања, односно да ли оне свој развој виде кроз креирање новог произода (за којима постоји значајна и растућа пажња), или у одржавању постојеће технологије којом, себично, контролишу своју одрживост? Наравно, отвара се и питање спремности ових институција да прихвате да се њихова мисија, поред традиционалне (настава и наука) односи и на активно учешће у подршци развоју друштва (трећа мисија).

\section{Предузетничко биће спорта - искорак ка трећој мисији универзитета}

Физичка активност савременог човека је лични подстицај који је испуњен и друштвеним вредностима и која све више функционише у комерцијалном окружењу. Она добија обрисе индустрије која садржи већи број међузависних чинилаца, као што су процес, услуга, роба, простор, људи, информације... Физичко вежбање је простор само-запошљавања и тржиште на коме се у САД годишње обави промет од око 215 милијарди долара (по подацима из 2015. године), око 160 милијарди евра у ЕУ, или око 15 милијарди фунти у Великој Британији. По подацима Уједињених нација више од три посто годишњег светског богатства се ствара кроз ове и њима блиске индустрије. Оно што је важно истаћи је то да економски капацитет физичке активности није везан само за врхунски спорт, јер, како анализе показују, мно- го веће су комерцијалне могућности у простору дечијег, омладинског, масовног и спорта особа са посебном бригом и потребама. Јавно - приватно партнерство је стратегија која је довела до ширења знања, већег запошљавања и комерцијализације физичког вежбања човека.

У европском оквиру су дефинисане кључне компетенције као исходи образовања, а које садрже знања, вештине и предузетничке ставове. Знање се описује као способност да се идентификују пословне могућности. Вештинама се проактивно делује унутар пројектног задатка (планирање, организација, управљање, руковођење, комуникација) у индивидуалном и тимском деловању. Предузетнички ставови су садржани у иницијативи, проактивности, независности и иновативности, мотивацији и чврстој оријентацији да се постигну циљеви. За учешће у креирању вежбања као производа којим ће се мењати природно, друштвено и економско окружење човека, потребна су знања и вештине, компетенције стручњака које се стичу кроз интердисциплинарну и мултидисциплинарну академску мрежу и образовање (формално, неформално, информално) до постдокторских студија.

Предузетништво се наметнуло као средство целовитог образовања, због чега данас нису страни ни називи као што су „пословни универзитет“, „предузетнички универзитет“ или „академски капитализам“. Универзитети су постали центри друштвено-економског развоја заједнице. Они су ти који кроз афирмацију треће мисије испуњавају очекивање уже и шире заједнице како у културном и уметничком, тако и у економском и друштвено-политичком развоју. Архитектура предузетничког универзитета је оријентисана према новој стратегији, руковођењу и пословној култури којом ће се мењати заједница и друштво (друштвено предузетништво) (Vorley and Nelles, 2009). Предузетнички капацитет и компетенције којима се тежи су оне које детерминишу студената као пословног појединца спремног да предузме иницијативе које ће довести до промена у пословном али и животном окружењу. Предузетничка активност дипломаца требало би да доведе до личног и друштвеног успеха, јер је предузетник особа која је вољна и способна да нове идеје преведе у успешну иновативну вредност (Marburger, 2011). 
Предузетника описује жеља за постигнућем, проактивност, иновативност, креативност, лидерство, али и вештине решавања проблема, планирања, преговарања, убеђивања, усмене и писане комуникативности, слушање... (Paunović i sar. 2012). Како своје иновативне и креативне активности реализује у економском али и друштвеном окружењу (укључујући спорт), предузетника красе социјална компетентност, широко интердисциплинарно и мултидисциплинарно знање из матичне али и других научних и практичних области деловања.

Значајан део вештина које красе предузетника стичу се његовим одрастањем кроз бављење спортом. Тако је потврђено да спорт подстиче: функционисање у складу са правилима; кооперативност; солидарност; постигнуће, али и развој карактера кроз одлучност, иницијативу, самоодређеност; креирање, толерисање и функционисање под стресом и уз висок степен ризика; постављање и решавања проблема; трагање за најбољим путем; деловање кроз тим и организовану мрежу... Данас, много више у односу на крај 19. и почетак 20. века „Кубертенови спортисти” имају дужност према себи, према савршенству, виртуелности, или ономе што су стари Грци називали арете, и код којих је спорт био резервисан за најбоље (аристон) и добро одгојене (елеутхерион), којима су додељиване физичке и моралне врлине (од племића се очекује да буде калос и агатхос, згодан и добар). Може се закључити да је много тога заједничког између спортисте и предузетника, тако да је оправдана интенција пословног света да добре спортисте преводе у предузетнике, односно настојање друштва да се кроз спорт, од најранијег школског узраста, стичу и оне вредности које ће бити афирмативне за рад у предузетничком окружењу (Јевтић, 2014).

Образовање у предузетништву и спорт данас се сагледавају као средство целовитог образовања. У том смислу, неопходно је и јасно дефинисати друштвеног предузетника који је продуховљен, социјално и етички вођен појединац који тражи нове могућности и додатну вредност за заједницу кроз иновације које воде до ефикасне праксе у јавним сервисима и које подстичу вредности друштва (Brooks, 2007). У литератури се друштвено предузетништво посматра као вишедимензионални конструкт предузетничког понашања, које се реализује са циљем остварења друштвене мисије. Реализација друштвене мисиje, а не стицање личног богатства, је критеријум друштвеног предузетништва којим се промовише и одрживост животне средине, друштвеног прогреса, непрофитних организација (Ratten, 2011b).

Друштвено предузетништво се реализује унутар непрофитног сектора, а резултат је ангажовања људског капитала и стратегија којима се мењају чланови заједнице, њихово окружење и само друштво (Kessene, 2005). Оно се налази између пословне и доброчинитељске активности и њиме се подстиче решавање проблема кроз афирмацију физичке активности која води до социјалне инклузије, борбе против социјалних проблема, очување животне средине, здравствене просвећености и слично. Отпочиње препознавањем постојања проблема, диференцирањем начина у његовом решењу, следи концепт или нацрт решења, дефинисање и обезбеђење ресурса, покретање предузетничке активности, окончање и афирмација послова (Brooks, 2007).

Мрежа којој се тежи у предузетништву, и која повезује актере пословне иницијативе је основа хоризонталне и вертикалне повезаности каква већ постоји у бићу спорта. Самим тим, ова мрежа може да буде основ за друштвени капитал кога чине појединци, удружења, асоцијације који, између осталог за циљ имају и развој и искоришћеност друштвене стране физичког вежбања (Јевтић, 2014).

Спорт за предузетништво је интересантан термин и концепт који за простор свог деловања има и „скривене мреже“ које су резултат пријатељстава која су развијана кроз спорт и која се даље негују кроз пословни и приватни живот. Мреже су постојећи друштвено - спортски капитал који се може планирати и користити за развој заједнице и побољшање живота њених чланова. У мање развијеним земљама, очигледно је да се друштвени капитал спорта не користи у циљу развоја друштва, односно у развијеним земљама физичка активност се користи за развој друштвеног капитала. Мрежа, која се осигурава унутар спорта, повезује се са мрежама других професија и тако, заједно јачају друштвену размену. Универзитети и спортска активност студената је идеално место за успостављање веза које ће се неговати зарад приватних и пословних разлога. 


\section{ТРЕКА МИСИЈА УНИВЕРЗИТЕТА И НАУЧНИ ЧАСОПИС „ФИЗИЧКА КУЛТУРА“}

У међународно препознатим „спортским наукама“ се уочава застој од 17 година између окончања истраживачких студија и њиховог трансфера у праксу, па чак, и тада се уочава да се ради само о делимичном трансферу освојених знања и праксе (Thoma et al, 2016). У процесу трансфера нових знања и праксе постоји неколико корака које је потребно испунити, и на сваком од њих, научни часопис „Физичка култура“ има простор и улогу за нову стратегију и деловање у правцу унапређења „природног знања“ и вредносно усавршавање друштва кроз културу, уметност и науку коју доноси физичко вежбање.

Расправом о трећој мисији универзитета у законској регулативи Србије, али пре свега из разлога афирмисања вредносних атрибута физичке активности на развој појединца и друштва, отваpa се и питање часописа „Физичка култура“ који, као водећи национални часопис у Србији, покрива научну област физичко васпитање и спорт. У Импресуму је записано да је ово званични часопис Универзитета у Београду, Факултета спорта и физичког васпитања, у којем се објављују радови из области спорта, физичког васпитања и рекреације, као и из сродних биомедицинских, хуманистичких, друштвених и природних наука. Појавни облици физичке културе (спорт, физичко васпитање и рекреација) у претходном изразу су, вулгарно, изједначени са (сродним) наукама. На конфузно изречен циљ и поље деловања, као одговор у процесу преевалуације за сврставање у научне базе, од стране Scopus-a је наведено да „Физичка култура“ мора имати јасан и концизан циљ и поље деловања..., да не сме прихватати радове који су ван оквира - делокруга Часописа..., као и да је међународна видљивост публикованих радова ниска. Како се ова видљивост вреднује на основу цитираности публикованих радова, и, како се по наводима Scopus-a мерење одвија у простору спортских наука, то је потребно изнова разматрати циљ и мисију Часописа, јасно одредити поље деловања. Дакле, за увођење „Физичке културе“ у међународне базе упитно је и административно додељен назив науке „Физичко васпитање и спорт“. Назив часописа „Физичка култура“ није проблематичан, чак шта више у одговору
Thomson-Reuters-a, а на захтев за укључење Часописа у њихову базу, назначено је да је „физичка култура веома компетитивно поље истраживања“. Дакле, трагање за парадигмом Часописа заснованој на националном и интернационалном препознавању и вредновању, треба започети променама које у првом кораку мора учинити издавач (питања афилације, самог издавача, дефинисање јасне мисије, циља и научног простора деловања...). Следе кораци редакције (издавачки одбор...), главног уредника (уредници области и поља, рецензенти...), тематско одређења аутора. Не мање важна су и питања дизајна, стратегије на друштвеним мрежама, веза са конференцијама, националним и међународним стручним, научним и спортским организацијама.... Наравно, све ово је детерминисано и буџетом! Ипак, до наведених и других циљева се не стиже изразом да се ради о званичном научном часопису Универзитета у Београду, већ, и пре свега, потребом ангажовања „целине“ стручне и научне заједнице Србије и региона који гравитира овом Часопису.

\section{Часопис „Физичка култура“ за професије и занимања у физичком вежбању}

Усмеравајући ток ове расправу са позиције разумевања односа науке Физичко васпитање и спорт и треће мисије универзитета, уочава се један број недоумица, од којих, за ову расправу о мисији научног часописа „Физичка култура“ и неку нову уређивачку парадигму, треба размишљати о следећим: 1. стварност високог образовања у простору НФВС је постојање државних и приватних факултета, од којих се, велики број ових других, унутар своје програмске оријентације, определило за изучавање управљачке, али не и лидерске и научне стране физичке активности-вежठања; 2. упитна је „осетљивост“ институција формираних декретом државе из периода социјализма на питања континуума човекове физичке активности и њен капацитет да, у 21. веку, равноправно детерминише културне и економске вредности; 3. питање је да ли запослени, па и сами дипломци обе групе институција разумеју предузетништво, афирмацију иницијатива, иновација и пословних вештина у простору физичког васпитања, спорта и рекреације; 4. није лако утврдити да ли је, и колики искорак којим би се афирмисао онтолошки и аксиолошки континуум научне области, а који се и данас, како је то било 
у прошлим временима, одвија од њене културне до економске стварности, од субјективних до објективних вредности, од спортске до пословне и бизнис функције спортске организације (Слика 3, дато кроз пример спорта).

\begin{tabular}{|c|c|}
\hline $\begin{array}{c}\text { (а) СПОРТ КАО КУЛТУРНО И } \\
\text { ДРУШТВЕНО ДОБРО }\end{array}$ & $\begin{array}{r}\text { СПОРТ КАО } \\
\text { ЕКОНОМСКО ДОБРО }\end{array}$ \\
$\begin{array}{c}\text { (б) СУБЈЕКТИВНЕ - „романтичарске“ } \\
\text { вредности спорта }\end{array}$ & $\begin{array}{c}\text { ОБЈЕКТИВНЕ - „,иросветитељске } \\
\text { вредности спорта }\end{array}$ \\
\hline
\end{tabular}

\begin{tabular}{|c|c|c|}
\hline (в) Спортска функиија & Друитвена функција спортске & Пословна и бизнис функиија \\
спортске организације & организације & спортске организације \\
\hline
\end{tabular}

Слика 3. Онтолошки (а) и аксиолошки континуум (б) спорта, од спортске до пословне функције спортске организације (в) (Јевтић, 2014)

Анализа акредитационих пријава показала би постојање изјава обе групе факултета на сличност у планским и програмским документима са најмање две иностране - европске високошколске установе. Програмска сличност отвара питање образовних исхода, пре свега, да ли програми домаћих факултета воде до кадрова и њихове компетентности да развијају друштво Србије, индустрију и технологију спорта - физичког васпитања - физичке рекреације... Треба нагласити да су образовни исходи прецизно измерена тврђења мисије којом водећи светски универзитети обезбеђују екстерно вредновање програма и институције и којима усмеравају просперитет струке, науке, друштва и свршеног студента. Исходи воде до стручњака који су образовани, обучени вештинама и које описују компетентности за захтевно и разуђено тржиште рада. Самим тим, постављају се нова питања, као шти су: какав је однос образовних исхода и тржишта рада; да ли се у Србији одвија образовање за живот и рад у капиталистичком друштвеном уређењу; или да ли домаћи факултети образују кадрове који могу бити лидери у струци и друштву; односно, да ли је пословна нада свршених студената усмерена ка тржишту којим доминира јасно профилисана струка или је то утопија која их одржава у старом и превазиђеном? Одговори на ова или било које од претходно наведених недоумица и питања захтева размишљање о томе колико су кадрови, струка и њена научна област еманциповани за послове и мисију високог образовања у 21. веку! Одговори на претходна, и многа друга питања, могу се црпети из анализе вектора вредносних промена друштва сходно којима се мењала и парадигма за изучавање физичке активности (спорта) човека (Слика 4).

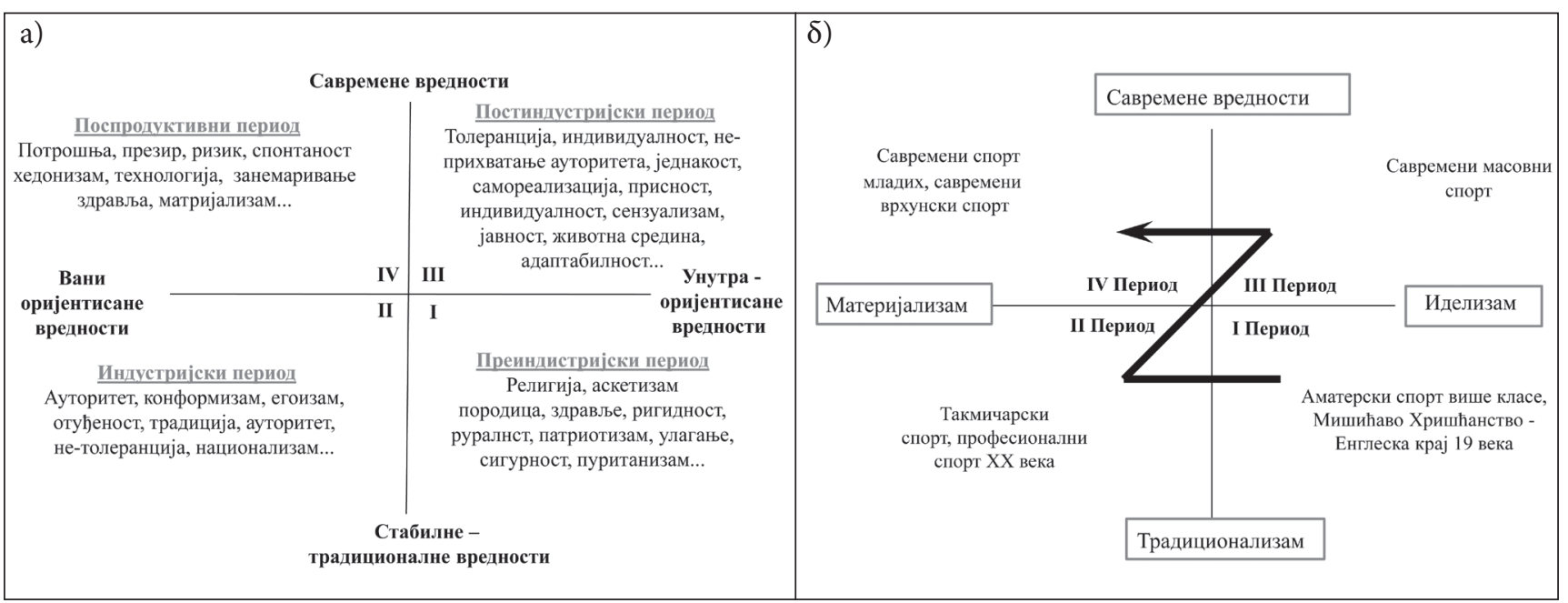

Слика 4. Периоди развоја друштва (а) и вредности спорта кроз периоде његовог развоја (б) (модификовано према: Jarvie, 2006, Brevik, G.) 
Основним претраживањем индексираних база уочава се да се мали број домаћих аутора бави везама физичке активности, предузетништва у спорту, предузетничким универзитетом и-или трећом мисијом универзитета (Јевтић, 2014). Импликације се могу наслутити, а то је мали број оних академаца који ће са универзитетском дипломом трагати за пословном иницијативом или радним местом у окружењу које „измиче“ држави као послодавцу. Колико је тога о чему струка треба да говори, чиме да се бави, тежи, објашњава, изучава.... у ком правцу треба и сама да се мења - еманципује... мора се наћи у предмету националног часопис „Физичка култура“ и његовим сервисима (блог). Анализом Слике 5 лако је утврдити да се систем физичке активности (физичко васпитање, спорт, физичка рекреација, запослени, волонтери, публика....) у Србији налази у првом или „бирократском квадранту“ - са јаким утицајем државе (A), те да пут до предузетничке конфигурације, како система спорта тако и самог универзитета (Слика 1) води и кроз научни часопис „Физичка култура“.

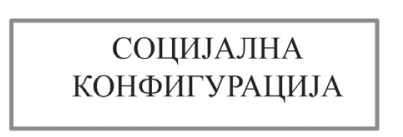

Усмереност ка програмима, учешћу, културним вредностима, дугогодишњим инвестицијама Изградња капацитета Поверење, развој заједнице... Децентрализација, јавни сектор
као партнер у постизању промена

\begin{tabular}{c} 
КОНФИГУРАЦИЈА \\
ЗАДАТКА \\
\hline
\end{tabular}

Волонтерско ангажовање и масовност Краткорочни циљеви, Оријентација ка процесу, услуга Иновативност,експанзија, адаптабилност

Праћење и вредновање учинка
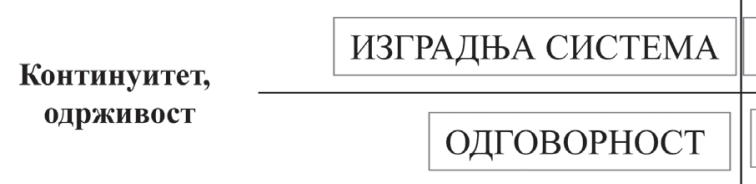

АДАПТАБИЛНОСТ

ЕФИКАСНОСТ

\section{Иновативност компетитивност}

Јак државни сектор управљања спортом, Усмереност ка регулацији и мониторингу од стране власти,

Неповерење, предрасуде, злоупотребе, Питање поштовања специфичности и аутономије

БИРОКТРАТСКА КОНФИГУРАЦИЈА

Централизација у преносу одлука и специфичних захтева државе

Слика 5. Конфигурације и вредновање националних система физичке активности - спорта у ЕУ (Vocasport (2005)

\section{ЗАКЉУЧАК}

I Савремени спорт, физичко васпитање и физичка рекреација се сагледавају и кроз додатну вредност, а до које се долази применом знања и технологија у планирању, изградњи и афирмацији ефеката вежбања усмерених ка савременом начину живота, потребама појединца и друштва. Савремени производ ових, појавних облика физичке културе - ентитета, доводи до вишег квалитета живота, подстиче животно (друштвено и природно окружење), утиче на формирање нових радних места, креира нове производе и радне профиле.... ( пословно окружење).

II Знања која су потребна да би се физичко вежбање и даље развијало и тако утицало на појединца и друштво, чине испреплетану мрежу теоријских и емпиријских чињеница, међу којима су оне које су повезане са образовањем и 
васпитањем, здрављем, комуникцијама, уметношћу, културом, екологијом, аксиологијом природе - културе - вежбања, еко - блиских технологија, бизниса, али и међународних односа и политика. Предмету изучавања припадају и економски ӣроблеми (економија, маркетинг, менаџмент, планирање). Интензивно се елаборирају проблеми истраживања унутар самих спортских наука (спорт, здравље, допинг, биомеханика, технологија тренинга...), социолошких проблема физичке активности (друштвени аспекти, радна места, друштвена реформа, демократизација, политика, парламентаризам, волонтери...), историјско-политички, као и социо-културни, филозофски и образовни простор. Корпус интрдициплинарног и мултидисциплинарног знања и актуелна пракса могу да чине оквир за дефинисање области научног часописа „Физичка култура“" унутар науке, културе и уметности физичке активности!

III Универзитети су постали центри друштвено-економског развоја заједнице. Они су ти који кроз афирмацију треће мисије испуњавају очекивање уже и шире заједнице како у културном и уметничком, тако и у економском и друштвено-политичком развоју. Архитектура „предузетничког“ универзитета је оријентисана према новој стратегији, руковођењу и пословној култури којом се мења заједница и друштво (друштвено предузетништво). На универзитетима у Србији, већ осамдесет година се изучава биће, знања, вредности, пракса.... физичког васпитања, спорта и физичке рекреације, остало је да се организује трансфер према појединцу, заједници и са циљем просперитета друштва.

IV Пуна афирмација „предузетничког“ универзитета омогућена је и реализацијом треће мисије универзитета. За ефикасно и целисходно кретање иновација ка друштву неопходно је успоставити и канцеларију за трансфер технологије. Издавачка делатност, самим тим и научни часописи, зборници радова са конференција, техничко-технолошке солуције... само су нека од средстава којима је могуће унапредити трансфер знања и технологије од универзитетских катедара до заједнице и друштва. Канцеларије за трансфер технологије су факултетске структуре путем којих наставници, сарадници, истраживачи и студенти комуницирају са „чиниоцима“ ван универзитета. Закон о високом образовању Србије препознаје технолошке паркове, инкубаторе, одељења за професионални развој, континуирану едукацију... Ова или слична пословна решења и њихова оријентација у простору науке „Физичко васпитање и спорт“ биће могућа само са прихватањем културе промена, организационих и продуктивних вредности... које воде до еманципације припадајућих факултетских заједница и њихово превођење у виши ниво унверзитетског развоја.

V У процесу трансфера нових знања и праксе постоји неколико корака које је потребно испунити, и на сваком од њих, научни часопис „Физичка култура“ има простор и улогу за нову стратегију и деловање у правцу унапређења „природног знања“ и вредносно усавршавање друштва кроз културу, уметност и науку коју доноси физичко вежбање.

VI Часопис „Физичка култура“, у контексту афирмације треће мисије универзитета и трансфера иновација ка друштву и пракси, може стићи до хетерогених корисника знања (моторичких и когнитивних) у простору човековог физичког вежбања. Часопис, поред резултата базичних и апликативних истраживања, треба да промовише знања од значаја за друштво, заједницу, предузетника у физичком вежбању.... Когнитивна и моторичка знања усложњавају очекивања корисника, самим тим и процес трансфера. У ту сврху, друштвени медији су једно од средстава у ширењу знања, али и отварање стваралачког дијалога актера струке и праксе наука повезаних са физичким васпитањем, спортом и физичком рекреацијом. Креирањем блога часописа „Физичка култура“ на друштвеним мрежама био би омогућен пренос видео записа и отварање двосмерног комуникационог канала између издавача, уредништва, аутора, рецензената и корисника знања. 


\section{ЛИТЕРАТУРА}

1. Brevik, G. Core values in athletics. Un published conference presentation. in pp.

2. Biegank, K.A., Huberty, L.L. (2015). Analyzing the organizational structure of the community engagement activitiesof profesional sport teams in the United States. Int. J. of Humanities and Social Science Invention 4:8:26-40.

3. Brooks, C.A. (2007). Social Entrepreneurship: A modern approach to social value creation. Prentice Hall.

4. Bruyant, J.A.P. (2000). Defininf the fields of research in enterpreneurship. J of Business Venturing, 16:165-180.

5. Clancy, P., Dill, D.D. (2008). The Research Mission ot the University. Policy reforms and institutional response. Rotterdam, Boston, Taipei: Sense Publisher.

6. Domazet, D., Adižes, A. (2014). Primen koncepta preduzetničkog - inovativnog univerziteta - put ka stvaranju nove idustrije znanja i razvoja savremenog otvorenog univerziteta. Tehnologija, kultura i razvoj, Zbornik radova 21: 23-38. Beograd: Udruženje Tehnologija i razvoj.

7. Hagen S. (2008). From tech transfer to knowledge exchange: European universities in the marketplace. In The University in the Market, Edited by: Engwall, L and Weaire, D. London: Portland Press.

8. Jarvie, G. (2006). Sport, Culture and Society. London, New York: Routledge.

9. Jevtić, B. (2014) Sport i preduzetništvo. Tehnologija, kultura i razvoj, Zbornik radova 21: 122-135, Beograd: Udruženje Tehnologija i razvoj.

10. Jevtić,B., Radojević,J., Juhas, I., Ropret, R. (Ur) Dečiji sport od prakse do akademske oblasti. Beograd: Fakultet sporta i fizičkog vaspitanja,

11. Kesenne, S. (2005). Do we need an Economic impact study or a Coast-Benefit-Analysiy of a Sport Event? Europ. Sport Manag. Quarterly, 5:2: 133142.

12. Kurbatov, V.S. (2015). The mission of contemporary university through the lense of time and space. Науковии вісник. Серія Філособія, 44: 176-184.

13. Marburger III, H.J. (2011). Science, technology and inovation in a $21^{\text {st }}$ centry contex. Policy Sci, 44: 209.
14. McDonald, M. A. (2009). Practicing community engaged research. Retrieved November 26, 2011, from https://www.dtmi.duke.edu/about-us/organization/duke-center-forcommunity-research/Resources/comm-engaged-research.pdf/

15. Paunović, B., Nikolić, M., Stosković, M. (2012). Importance of entrepreneurship education for economic development of Serbia. In Radović-Marković, M, Grozdanić, R., Krumov, K Ed: Employment, education and enterpreneurship. The first international conference Vol. 3. Beograd: Faculty of Buisiness Economics and Entrepreneurship.

16. Pupovac, D. (2014). Obrazovanje - laka industrija ili kovčeg panaceje država jugoistočne evrope. Tehnologija, kultura, razvoj, Zbornik radova 21:79-90. Beograd: Udruženje Tehnologija i razvoj.

17. Ratten, V. (2011a). Social entrepreneurship and innovation in sports. Int. Jour. for Social Entrepreneurship and Innovation 1(1)42-54.

18. Ratten, V. (2011b). Sport-based entrepreneurship: toward a new theory of entrepreneurship and sport management. In. Entrep. Manag. J, 7: 57-69.

19. Scott, C.J. (2006 ). The mission of the University: Medieval to postmodern transformations. J. of Higher Education 77:1-39.

20. Smith, C.T.A.,Westerbeek, M.H. (2007). Sport as a vechile for deploying corporate social responsibility. The J. of Corporate Citizenship 25: 5-12.

21. Talbot, M., Stringer, C., Neal, L et 1 (2005). Community sport - Oral and written evidence. London: House of Commons.

22. Thoma, J., Walker, TW, Miler.S, Cobb,A., Thomas, S.J.(2016). The Olympic legacy: Journal metric in sports medicine and dentistry. J. Int.Soc. Prevent Communit Dent 6:501-508.

23. Vocaport (2004). Vocational education and training in the field of sport in the European Union: situation, trends and outlook. EOSA, Lio

24. Vorley, T., Nelles, J. (2009). Building Entrepreneurial Architectures: a conceptual interpretation of the Third Mission. Policy Futures in Education 7 - 3- 284-96. 


\title{
WISSENSCHAFTLICHE ZEITSCHRIFT „KÖRPERKULTUR“ IN DER MISSION ZUR ENTWICKLUNG DER WISSENSCHAFTLICHEN UND GESELLSCHAFTLICHEN GEMEINDE
}

\begin{abstract}
Zusammenfassung
Moderne Universitäten übernehmen die Rolle der Achse der Wirtschaft, die auf Wissen und innovativer Politik basiert. Sie beschäftigen sich mit gesellschaftlichen Problemen, vor allem mit dem Bedürfnis nach allgemeiner Entwicklung, sowie mit Problemen, die vernachlässigt oder von seiten der Verwaltungsdistanzen nicht gelöst werden. In Serbien wird ein Projekt realisiert, das außer zwei schon existierenden Missionen (Unterricht und Forschung) eine dritte Mission der Universitäten entwickeln und implementieren soll, die aus drei Säulen besteht: Wissenstransfer - Technologien und Innovationen; kontinuierliches Lernen; sowie Aneignung und Anwendung gesellschaftlich verantwortlichen Verhaltens von seiten der serbischen Universitäten. Die Veränderung zu einer modernen, unternehmerischen Universität sollen auch Veränderungen der Mission der wissenschaftlichen Zeitschriften begleiten, weil der gemeinsame Nenner von Schöpfern und Disseminatoren des Wissens die Prosperität der Wissenschaft und der Gesellschaft ist, die auf Innovationen gründet. Gemäß all dem Angeführten bezieht sich der Gegenstand dieser Arbeit auf die vorausgesetzte Rolle der Universität in der Entwicklung der Gemeinde bzw. auf die Kapazität der wissenschaftlichen Zeitschrift „Körperkultur“, ein Intermedium zwischen Unterricht, wissenschaftlicher und gesellschaftlicher Mission der Wissenschaft „Körperkultur und Sport“ darzustellen.
\end{abstract}

Schlüsselwörter: DRITTE MISSION DER UNIVERSITÄT / UNTERNEHMERTUM / KÖRPERLICHE AKTIVITÄT / WISSENSCHAFTLICHE ZEITSCHRIFT / SERBIEN

Примљен: 01. 11.2017.

Прихваћен: 02.12. 2017. 